\title{
The elderly recognizing themselves as vulnerable to falls in the concreteness of the femoral fracture
}

\author{
Idoso reconhecendo-se vulnerável a quedas na concretude da fratura do fêmur \\ El anciano reconociéndose vulnerable a caídas en la realidad de la fractura femoral
}

\section{César Junior Aparecido de Carvalho', Silvia Cristina Mangini Bocchi'}

' Universidade Estadual Paulista Júlio de Mesquita Filho, Medical School of Botucatu, Postgraduate Program in Public Health. Botucatu, São Paulo, Brazil.

\begin{abstract}
How to cite this article:
Carvalho CJA, Bocchi SCM. The elderly recognizing themselves as vulnerable to falls in the concreteness of the femoral fracture. Rev Bras Enferm [Internet]. 2017;70(2):279-86. DOI: http://dx.doi.org/10.1590/0034-7167-2016-0392
\end{abstract}

\section{Submission: 07-21-2016 Approval: 09-30-2016}

\begin{abstract}
Objectives: understand the experience of the elderly with falls followed by femoral fracture and elaborate theoretical model of this process of lived experience. Method: qualitative research with theoretical saturation through analysis of the ninth nondirected interview of elderly who underwent such experience. Interviews were recorded, transcribed, and analyzed according to Grounded Theory. Results: three categories emerged (sub-processes): evaluating signs and symptoms of fracture after the fall; feeling sad and insecure with the new condition; and finding oneself susceptible to fractures. From realignment of these categories (sub-processes) we could abstract the central category (process), recognizing oneself as vulnerable to falls in the concreteness of the fracture. Conclusion: the theoretical model considering the Symbolic Interactionism signals the implementation of continued program for fall prevention, with teaching strategies that encourage the elderly to reflect on the concreteness of contexts in which there is risk of occurring injury to their health. Descriptors: Elderly; Accidents by Falls; Fractures of Femur; Care; Vulnerability.
\end{abstract}

\section{RESUMO}

Objetivos: compreender a experiência de idosos com quedas seguidas de fraturas do fêmur e elaborar modelo teórico desse processo de vivência. Método: pesquisa qualitativa com saturação teórica mediante análise da nona entrevista não diretiva de idosos que vivenciaram tal experiência. As entrevistas foram audiogravadas, transcritas e analisadas segundo a Teoria Fundamentada nos Dados. Resultados: emergiram três categorias (subprocessos): avaliando sinais e sintomas de fratura após a queda; sentindo-se triste e inseguro com a nova condição; e descobrindo-se suscetível a fraturas. Do realinhamento dessas categorias (subprocessos), foi possível abstrair a categoria central (processo), reconhecendo-se vulnerável a quedas na concretude da fratura. Conclusão: o modelo teórico à luz do Interacionismo Simbólico sinaliza a implementação de programa continuado de prevenção de quedas, com estratégias de ensino que estimulem o idoso a refletir sobre a concretude de contextos nos quais haja risco de ocorrências do agravo à sua saúde.

Descritores: Idoso; Acidentes por Quedas; Fraturas do Fêmur; Cuidado; Vulnerabilidade.

\section{RESUMEN}

Objetivos: conocer la experiencia de ancianos con caídas seguidas por las fracturas del fémur y elaborar un modelo teórico de la experiencia de este proceso. Método: investigación cualitativa con la saturación teórica, mediante el análisis de la novena entrevista no directiva de ancianos que experimentaron esta experiencia. Las entrevistas fueron audio grabadas, transcritas y analizadas según la Teoría Fundamentada en los Datos. Resultados: surgieron tres categorías (sub): la evaluación de los signos y síntomas de la fractura después de la caída; sentirse triste e inseguro con la nueva condición; y descubrirse susceptible a las fracturas. Después de la realineación de estas categorías (subproceso), fue posible abstraer la categoría central (proceso), reconociéndose vulnerable a caídas en la realidad de la fractura. Conclusión: el modelo teórico a la luz de la interacción simbólica señala la aplicación del programa continuo de prevención de caídas, con estrategias de enseñanza que fomentan los ancianos a reflexionar sobre los contextos concretos en los que existe un riesgo de daño a su salud.

Descriptores: Anciano; Accidentes por Caídas; Fracturas Femorales; Cuidado; Vulnerabilidad. 


\section{INTRODUCTION}

With the aging of the world population, falls and their consequences to quality of life of elderly and family caregivers, as well as to the health system, represent a public health problem and are the subject of studies in Brazil ${ }^{(1-2)}$, similarly to what occurs in other countries ${ }^{(3-5)}$.

It is considered as fall the unintentional displacement of a body to a level that is lower than the starting position, with incapacity of correction in a timely manner, determined by multifactorial conditions that compromise the individual's stability $^{(6)}$ and cannot be related to a single cause ${ }^{(7)}$.

Falls result from loss of postural balance and can be caused by primary problems of the osteoarticular or neurological system or even by adverse clinical condition affecting secondarily the mechanisms of balance and stability ${ }^{(7)}$, according to the following risk factors:

a) Physical: reduction of gait and balance, functional decline with uncoordinated movements, and reduced sensory functions (visual, tactile, auditory, tactile, vestibular, and proprioceptive disorders);

b) Behavioral: decline of everyday activities (much or little exercise, walking quickly, uncomfortable shoes);

c) Psychological: fear of falling as a result of prior fall, stress due to financial difficulties, and sleep disorders;

d) Environmental: poor lighting of the house, bed height, absence of support in the bathroom, uneven or slippery surfaces, and social isolation;

e) Medicines: use of antidepressants, antiepileptics, anticholinergics, hypnotics and sedatives, cardiovascular drugs, hypoglycemic agents, diuretics and muscle relaxants, abusive consumption of alcohol and use of four or more medicines;

f) Associated diseases and their complications: neurological, cardiac, musculoskeletal, mental, among others ${ }^{(8)}$.

Brazil presents high prevalence of falls in the elderly (32.1\%), significantly higher in women $(35.0 \%)^{(9)}$ when compared to $\mathrm{Ni}$ geria $(23 \%)^{(10)}$ and China $(20 \%)^{(11)}$. Moreover, in a study conducted in the city of Niterói (RJ), it was observed that $78.2 \%$ of the fractures in the elderly had occurred in lower limbs ${ }^{(12)}$.

Although these data indicate a higher risk for certain groups, falls in the elderly and resulting fractures are common events around the world, associated with significant mortality and variations as to consequences ${ }^{(13)}$. This may be related to presence of comorbidities, longer hospitalization time, and complications arising from surgical procedures, such as general anesthesia ${ }^{(14)}$.

Reducing the risk of falls and of their consequences requires pondered and effective actions founded on a multidimensional approach, which is only possible by means of integrated and specialized action of a team ${ }^{(15)}$. The current model for fall prevention of the World Health Organization (WHO) is based on three interrelated and mutually dependent pillars: building awareness about the importance of prevention and treatment of falls; increasing the assessment of individual, social, and environmental factors that increase the probability of falls; and fostering the planning and implementation of interventions aimed to reduce the number of falls, based on the experiences of the target seniors ${ }^{(7)}$.

With this in mind - and considering, in the Brazilian elderly population, (a) the high prevalence of falls ${ }^{(10)}$; (b) the estimation of reaching 32 million inhabitants in 2025, representing 15\% of the population ${ }^{(16)}$, and (c) the need to implement fall prevention strategies based on the seniors' conception regarding the event $^{(7,17)}-$ it is questioned: How do the elderly from the city of Londrina conceive falls followed by femoral fractures?

In attempting to respond to such concern, this research was conducted with the aims of understanding the experience of the elderly with falls followed by femoral fractures and elaborate theoretical model of this process of lived experience.

\section{METHOD}

\section{Ethical aspects}

Research was initiated after approval of Research Ethics Committee (Research Ethics Committee of the Irmandade da Santa Casa de Londrina) and signing of informed consent for participation in research by the actors.

In order to preserve the anonymity of the authors' information, after the interviews were transcribed the digital files were deleted and all information that could identify the elderly were suppressed. Thus, these are identified only alphanumerically (A-1, A-2, A-3,...).

\section{Theoretical-methodological framework and type of study}

This is qualitative research, with comprehensive approach, using the methodological framework Grounded Theory $(\mathrm{GT})^{(18)}$ and Symbolic Interactionism ${ }^{(19)}$ as theoretical framework.

\section{Study scenario and actors}

The study was conducted with elderly ( $\geq 60$ years) submitted to surgery of fracture of femur between January 1 and December 31, 2010, in two large tertiary hospitals of Londrina, contracted to the Unified Health System.

They were located through listings provided by the Medical and Statistical Record Services (SAME) of the Institutions, containing names, addresses, and phone numbers of all elderly who underwent surgery in the period. Of these, we selected those with addresses included in the five urban regions covered by the Family Health Strategy (FHS).

After organizing the lists in decreasing order, one of the researchers conducted the first contact by phone, with introduction and explanation about the purpose of the research, to invite them to participate in the study. As usually the call was answered by a family member, if the invitation was accepted, the researcher confirmed with this person if the elderly showed cognitive and communication capacity to be interviewed later. Under these conditions, home visit was scheduled so the researcher could ask about the elderly's own interest to cooperate with the research, as well as schedule other day and time, if considered necessary.

\section{Data source}

Data collection was performed through nondirected interview, having as guiding question: "How was your experience 
with the fracture of femur?" Individual interviews with audio recording, conducted from July to November 2012 by one of the researchers with training in data collection technique, in the seniors' houses, at schedule time, in order to respect the confidentiality of their information.

\section{Data analysis}

After the interviews were concluded, they were transcribed and submitted to manual analysis by one of the researchers and validated by the second, with training and experience in implementing the methodological framework of the Grounded Theory $(\mathrm{GT})^{(18)}$ :

- Microanalysis: detailed line-by-line analysis, necessary to generate initial categories (with their properties and dimensions), suggesting relations between them and a combination of open and axial coding;

- Open coding: analytical processing of the data by means of which concepts, properties, and dimensions are identified. In this step, a large amount of encoded data is reduced by naming groups of items (codes) with similarity of meaning and, consequently, of development of concepts. A concept is the abstract representation of event, object, action, or interaction that a researcher identifies as being significant in the data. In the methodological framework employed, categories are concepts derived from data that represent phenomena. Concepts begin to form when the analyst initiates the process of grouping or classifying them in more abstract terms, into categories;

- Axial coding: process of relating the categories to their subcategories, according to their properties and dimensions, systematically. This step of analysis is important for the construction of the theory;

- Selective coding: process of integration and improvement of the theory. In the integration, the categories are organized around a central concept through various techniques: describe the history, using diagrams, classification, and review notes.

As recommended by this type of research, the steps of data collection and data analysis occurred at the same time until theoretical saturation was obtained based on analysis of the ninth interview. To this end, we used one of the strategies advocated by the methodological framework for validation of model found (Figure 1), recommending comparison of the model with the raw data, which proved able to explain the conception of fall in the experiential process of the elderly ${ }^{(18)}$.

\section{RESULTS}

\section{Characterization of the actors of the research}

Out of the nine actors of this study, six were women and three were men, aged 62 to 81 years, with six retirees, one farmer, one truck driver, and one housewife. Their income was two to seven minimum wages. In the rehabilitation process, eight presented full functional independence and one presented partial dependence on family caregiver. It is noteworthy the difficulty to include experiences of the elderly who had not re-established their independence, either due to the passing of some or because they were living the experience a second time.

The experience of the elderly with fall followed by fracture

Data analysis according to Grounded Theory enabled understanding the interaction of the elderly with the fall followed by fracture and establish theoretical relations between the components (categories and subcategories). Based on that we could develop the explanatory and analytical process for the actions and interactions concerning the experience, represented by the central category, recognizing oneself as vulnerable to falls in the concreteness of the femoral fracture.

This process unfolds into three sub-processes, which represent the symbolic meaning assigned by the elderly to the fall followed by fracture, arising from chaining of the categories assessing signs and symptoms of fracture after falling, feeling sad and insecure with the new situation, and finding oneself susceptible to fractures.

From the interrelation of these categories with the central category, we abstracted the theoretical model that represents this experience (Figure 1).

Recognizing oneself as vulnerable to falls in the concreteness of the fracture is the theoretical model that is representative of and abstracted from the interactional movement undertaken by the experience of the elderly with fall followed by femoral fracture. The process signals one's recognition of susceptibilities to falls being constituted after the trauma, considering the reflections for understanding the context of feeling surprised by an experience that causes physical and psychological suffering.

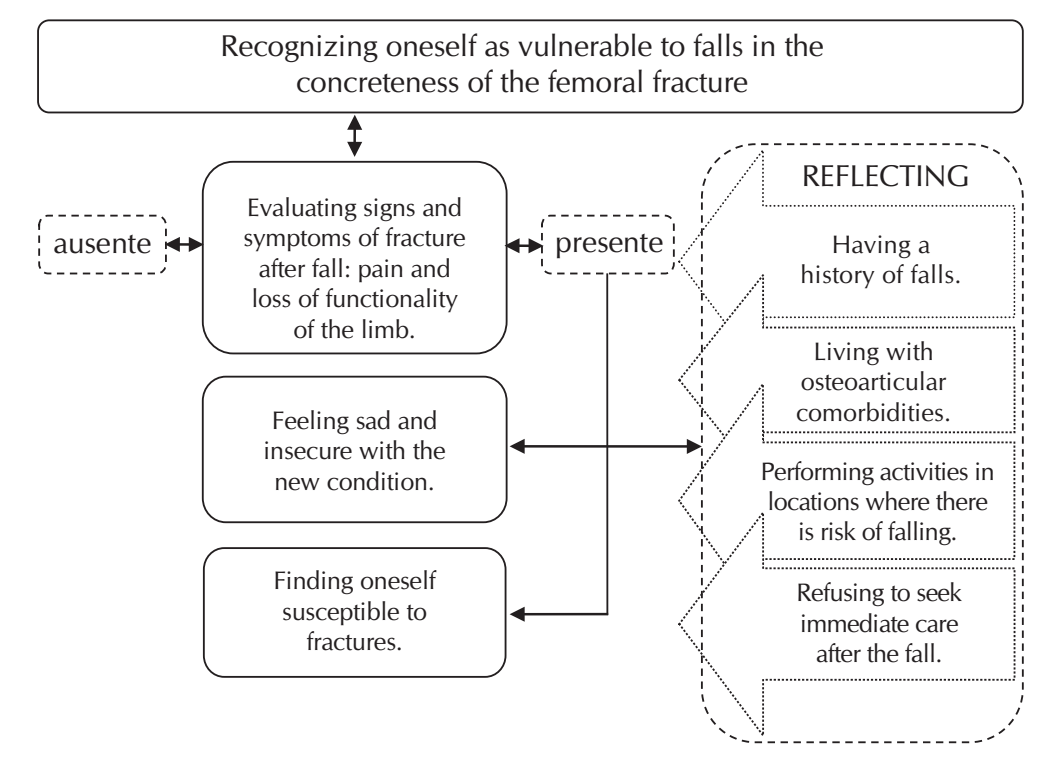

Figure 1 - Theoretical model - Recognizing oneself as vulnerable to falls in the concreteness of the fracture: the experience of the elderly 
In situation of fall, the process starts immediately with the elderly evaluating signs and symptoms of fracture, perceptible in the painful intensity in lower limb, limitation to move it and, especially, difficulty of supporting body weight on the limb to stand, as reported:

[...] When I fell, I felt pain [...] and [...] a person came to help me stand [...], I tried to support my leg on the floor, I couldn't [...].Then I thought: "My leg is broken" [...]. (A-1)

[...] I took a tumble and fell a little aside. At the time I thought [...] that I was going to get up. [...] Then I felt a pain and so I tried to get up and couldn't. [...] My nephew came and said:

- Hey, Auntie, what happened? [...]

- I fell! - I said.

- Then try to stand.

- I think I can't! [...] - Then I couldn't in fact. [...] I said to him: - I broke my leg [...]. (A-8)

As pain is one of the main signs for the elderly to recognize a fracture, in cases it shows no significant intensity and in the absence of immediate compromise of limb functionality, the hypothesis of fracture will only be reconsidered later, as diagnosis by radiological examination, or when the elderly is exposed to new events that may aggravate bone and muscular continuity, making evident the classic signs and symptoms, as reported by the respondents:

[...] I didn't have any pain. [...] Hit the floor on the hips [...] and [...] I didn't feel pain, I felt nothing [...]. I even waited a while for my nephew to come and go by car to the hospital. At the hospital, I had to wait a long time to be serviced. As it didn't hurt, I didn't think it had broken, only after x-rays I could recognize that the femur had broken [...], but if it wasn't for that, to me, it would have been just a tumble [...]. (A-5)

[...] I broke my leg during a walk [...], but I didn't feel pain. I came home walking slowly, then, when I was showering, I slipped [...] and my legs were kinda paralyzed and I realized I could no longer stand. I was on the floor. I called my husband to help me. My son took me to the hospital and after a long time they found a fracture. (A-1)

The experience shows that this senior's psychic distress is not only due to physical pain, but to the mental dynamism, which, even considering the fracture a hypothesis, immediately projects the difficulties with the next steps to be faced, such as hospitalization, surgery, rehabilitation at home, and life plan. These facts lead to the second subprocess, called feeling sad and insecure with the new condition of fractured elderly, exposed to the weaknesses of the age and the consequent uncertainties with the future.

The senior who initially was unconcerned with the evaluation of risk of fall and fractures, when experiencing such a situation, usually destabilize emotionally, being bored, nostalgic, and lonely. Often, this senior is inconsolable because of pain, of functional dependency, and of uncertainty as to achieving full rehabilitation. As the situation is imposed, the elderly feel constrained to accept it and deal with all stages of treatment:
[...] I was so sad [...].I was lying there.I felt pain in the legs, [...] and also couldn't stand [...] and waiting for somebody to bring things. [...] It is the most horrible thing! [...]. (A-3)

[...] Sometimes I cried, because I wanted to get well, I thought it was taking too long, you know to treat the leg [...]. I am a person who can't stop, I do all chores at home, moreover, I also sewed, I've always done everything alone [...]. I saw her overwhelmed with home chores [...] and couldn't wait to treat my case [...]. (A-8)

[...] I feel really bad for not being able to walk and do the home chores, for not being able to take care of my grandchildren, who are four year old. You know aging how it is, mischief only [...]. I can't do anything, she there has to deal with everything, poor thing [...]. I feel very sad, ask her how I cry. I cry all the time [...]. (A-6)

[...] After a time at my son's house, I came home [...]. Then I was alone all the time. [...]. It wasn't always that my son could come here [...]. Only when he could come [...]. I felt very lonely [...]. (A-7)

[...] I felt very sad to see that my two aunts thought I wouldn't walk ever again [...]. Yeah, my sister also said I would never walk again [...]. Very sad to hear that [...]. (A-3)
[...] There were people who came here and sometimes said: - Will you ever walk again?
[...] At the time I thought:
- My God, I wonder if I'm not going to walk again? - I sometimes thought of it [...], very sad! (A-8)

In this context, the senior is led to the third subprocess, finding that one challenged risks and susceptibilities to fracture. Introspection leads to recognition of self, through reflections for understanding and then justifying the condition of fractured. This cognitive movement allows the recollection of the risk factors that contributed to the fall followed by femoral fracture, as well as the inobservance with regard to the complications related to the type of injury. Among them, we can cite: having a history of falls; living with osteoarticular comorbidities; performing activities in locations with a tendency to falls; and refusing to seek immediate care after the fall.

In addition to the fracture experience leading the elderly to reflect on the fall and its context as a reason for the incident, it leads to thinking about the history with the event, which leads to recognition as having a history of falls. Pre-existing health conditions are also remembered by the elderly as risk factors for fall followed by fracture, for example being living with osteoarticular comorbidities, such as those associated with uric acid and arthrosis, as reported:

[...] At the time of my fall I remember I was walking with some difficulty, because I had had a gout crisis and remained bedridden for a month without walking. (A-8)

[...] You see this leg is numb.It tingles and hurts. The doctors say it's because of my arthrosis, and that's what caused my leg to be paralyzed during the mass and made me fall and break my leg [...]. (A-9) 
Another risk factor remembered is the habit of performing activities at locations where there is risk of a fall, inside and outside home. Fractures occur, most of the time, due to lack of attention and care, also by family members, specially in relation to environmental obstacles: carpets, stairs, slippery and greasy floors, in addition to lack of grab bars in bathroom, potential risks for falls disregarded in the household environment. Furthermore, external environments, such as sidewalks and streets with uneven floors and hard to reach places can also cause falls, as reported:

[...] I was going to be examined at the clinic and stumbled on the bench [...], I hadn't seen the bench and it was too tight to pass [...]. (A-3)

[...] Oh, it used to be hard. The bathroom where I lived down there was very slippery and had stairs for access [...]. (A-7)

[...] You see, I took a tumble here at this door, coming from the kitchen to the living room. But I was walking with some difficulty and the floor was slippery and greasy, then you know [...], it happened! [...]. (A-8)

[...] I tripped on the sidewalk which was uneven, I wasn't able to take the step and I fell [...]. (A-5)

[...] Oh, I went there to get a rug to put in the bathroom and I don't know what I did that I slipped and fell on my back. There I couldn't get up, I called my husband to help me, even a slight movement was painful. [...] I thought, I broke my leg! [...]. (A-4)

Even with signs and symptoms of fracture in lower limb, the elderly can undertake a movement of negative coping, refusing to seek immediate care after the fall. At this time, the elderly still have no awareness regarding the seriousness of the event and expose themselves to complications caused by the fracture itself, as reported:

[...] I'm 62 years old and nothing like this has ever happened in my life. I've never fallen! I've never been involved in an accident! So, what happened? We're uninformed about it. We think that it happens with other people and not with us. But when it happens it's for real. A tumble as simple as that. I've jumped a lot down from the back of the truck and nothing's ever happened. I even fell upside down on the floor. Stuck in the ground and nothing happened. Now I fell sitting on the floor and it broke me everything! [...] I said:

- I'll go home driving the truck.

My boss said:

- No! Get on a plane! Don't come driving!

- No! - I answered.

- Get a driver!

- No! - I repeated.

I won't get a driver who in the end is gonna get me killed, 'cause we get a strange person who, sometimes, we don't know, and end up in an accident and killed. I talked to God:

- You Lord will take me home and I came all the way home [...].

Driving with a fracture from Salvador to Londrina was an act of madness. I was a long time with two fractures of the femur until I got medical care [...]. (A-2)

\section{DISCUSSION}

The study enabled understanding the interactional movement of the elderly with their experience of fall followed by femoral fracture while research object, represented in the theoretical model recognizing oneself as vulnerable to falls in the concreteness of the fracture. The process led to the conjecture that the susceptibilities of the elderly to the events are increased because recognition of risk factors related to such situations occur only after the trauma. This, therefore, constitutes a milestone for the reflection about the incidents, when it becomes possible to understand and justify the event.

Such behavior can be understood based on the assumptions of Symbolic Interactionism, which considers the human mind as symbolic action in relation to self. It is the activity that occurs continuously and uninterruptedly in active communication with self, through the use of symbols. As part of the activities of the mind, by consequence, the person develops signs for him/herself, defines and interprets meanings, producing sense for the elements of a given situation. Thus, the action is the response triggered by the interpretation made by the individual in interaction with a social object ${ }^{(19)}$.

In this study, we observed the elderly finding themselves susceptible to fall followed by fracture only after experiencing the concreteness of the facts. The possibility of fall followed by fracture occupies a plane of invisibility in the daily considerations of the elderly, as it did not correspond to a sensitive reality and, hence, were distant from everyday life.

Example thereof are the Malaysian elderly, who, although presented high risk for fall, only realized their vulnerability after the facts. They had not yet formed the conception of risk, due to considering the fall a stigma or because they had not suffered serious injuries ${ }^{(20)}$. The study corroborates the results of this research, showing that lack of foreseeability of the risk of falls and fractures, by the elderly, hinders their understanding and acceptance of the event when it occurs. In addition, the initial absence of symptoms leads seniors to consider themselves as healthy persons with resistant skeleton, especially when they have suffered other falls not followed by fractures ${ }^{(21)}$.

The results obtained in this research are supported by studies demonstrating no understanding by the elderly of their risk factors for falls and fractures and how much this attitude negatively affects their health ${ }^{(22-23)}$, in addition to causing overload to the family and to the health system. The most common adverse effects are sadness and insecurity because of the pain, of the state of dependence, and of the uncertainty regarding the full rehabilitation.

Studies point out the relation between these negative effects and decreased autonomy and functional independence caused by falls, even if for a limited time ${ }^{(24-25)}$. Difficulties faced by the elderly refer to restriction of activities, immobility, psychological damage, fear of suffering new falls and of risk of death, in addition to the family-related losses, financial cost, and availability for care.

This knowledge supports the findings of this study and reinforce that extrinsic risks (environment) and intrinsic risks (anatomical and physiological) increase the susceptibility of the elderly in relation to fracture after fall and to suffering during the rehabilitation process ${ }^{(26)}$. As observed based on data of 
this study on the understanding of the conditions that resulted in fractures, the elderly relate the risks to their own history of falls, to activities in inappropriate locations, inside and outside the house, and to the osteoarticular comorbidities.

In this sense, there are researches that indicate limitations preceding the fall - as osteoarticular diseases, environmental factors, among others - which subject the elderly to alterations in their quality of life. The consequence is a series of negative aspects in their daily lives, as the elderly are unable to enjoy an independent, active life ${ }^{(27)}$. We observed the lack of attention of the elderly in relation to such limitations, which makes them susceptible to falls. Only after experiencing them, they regain awareness concerning the possibilty of prevention. Therefore, actions of preventive nature in the elderly-fall-fracture interactional process lie in a mental plane of invisibility, emerging only after the fact is concretized ${ }^{(27)}$.

The results of this research are corroborated by the results of a multicenter study conducted with seniors of European countries $^{(28)}$ and by the results of other researches conducted with American seniors ${ }^{(29)}$. It was observed that one of the obstacles to prevent falls in the elderly is their own denial of the events and, often, the consideration that they are unavoidable.

The study with American seniors showed that they become aware in relation to the practice of preventing falls from the moment they realize the risk, that is, when they start to fall frequent$l y^{(30)}$. However, the group of Brazilian seniors studied here may be considered in situation of greater vulnerability compared with the American seniors, as the Brazilians only recognized themselves as susceptible to falls and fractures upon reflection on risks and causes after the concreteness of fracture.

Considering this finding, it is understood that this research achieved one of the recommendations of the WHO fall prevention model, which advocates planning interventions for preventing falls and hence fractures, based on the experience of the target population. It is essential to use educational strategies - individually or in groups - that continuously foster reflection on the subject by this population. Thus, it is enabled that the elderly, based on interaction, recognize their vulnerability and can then define their risk factors preemptively.

According to Symbolic Interactionism, interaction with self and with others leads the individual to make decisions that direct the course of action. This definition of the situation made by the actor is central with regard to the way the action will occur $^{(19)}$. Therefore, the individual needs to reconfigure oneself, giving oneself the opportunity to partake of the knowledge of professionals, as well as of the experiences of others who have experienced similar situations.

\section{Study limitations}

Notwithstanding the positive contribution, acknowledging that one of the limitations of this study is not having included a sample group of seniors who have experienced femoral fracture for the second time, which would be appropriate in future research, aiming to determine if the experience was sufficient to lead the elderly to better observe the risk factors for new falls. It should be noted that the formation of such sample group was not possible due to the difficulty in finding seniors who met the inclusion criteria.

Contributions to the fields of public policy, health, or nursing

It can also be affirmed that the abstraction of the elderly-fallfracture experience - through the theoretical model emerged and considering the Symbolic Interactionism - contributes by indicating that the use of teaching strategies that foster reflections about contexts in which there are harms to health lies in a plane of invisibility in the human mind. For the nursing area, such strategies can contribute significantly to stimulate the individual to adopt actions for self-care, by bringing this individual close to the concreteness of everyday situations of exposure. Thus, we suggest clinical research to test such hypothesis, in addition to evaluate the effectiveness of the theoretical model emerged from this study as educational resource to raise awareness of the elderly in relation to prevention of falls.

\section{FINAL CONSIDERATIONS}

This study, according to the GT, allowed to understand the interaction of the elderly with fall followed by fracture and, consequently, elaborate a theoretical model of this process of lived experience, named recognizing oneself as vulnerable to falls in the concreteness of the femoral fracture. The model indicated the elderly-fall-fracture interactional process occurring in a plane of mental invisibility and emerging only after the concreteness of the fact.

Moreover, the study enabled emphasizing the importance of planning the prevention of falls and fractures in the elderly and of the implementation of teaching strategies that lead them to reflect on possible situations that present risk of these accidents and to be aware of them in daily life.

It is expected that nursing professionals incorporate to their evaluation instruments for seniors an item that allows knowing their conceptions about falls and fractures. Through the study we could observe that knowledge as to what the elderly think about the risks of falls and fractures is a useful tool to assist in implementing health education and fall prevention activities based on the individual's risks.

\section{REFERENCES}

1. Antes DL, D'orsi E, Benedette TRB. Circunstância e consequência das quedas em idosos de Florianópolis: EpiForipa Idoso 2009. Rev Bras Epidemiol[Internet]. 2013[cited 2016 Apr 20];16(2):469-81. Available from: http://www.scielo.br/pdf/rbepid/v16n2/1415-790Xrbepid-16-02-00469.pdf

2. Gomes GAO, Cintra FA, Batista FC, Neri AL, Guariento LE, Souza, MLR, et al. Elderly outpatient profile and predictors of falls. Med J[Internet]. 2013[cited 2016 Apr 20];131(1):13-8. Available from: http://www.scielo.br/pdf/spmj/v131n1/1516-3180-spmj-131-01-13.pdf

3. Calha A. A condição sénior no Sul da Europa e na Escandinávia. Saúde Soc[Internet]. 2015[cited 2016 Apr 20];24(1):527-42. 
Available from: http://www.scielo.br/pdf/sausoc/v24n2/0104-1290-sausoc-24-02-00527.pdf

4. World Health Organization. Knowledge translation on ageing and health: a framework for policy development. [Internet]. 2012[cited 2016 Apr 20]. Available from: http://www.who.int/ageing/publications/knowledge_translation.pdf

5. Demura S, Sato S, Shin S, Uchiyama M. Setting the criterion for fall risk screening for healthy community-dwelling elderly. Arch Gerontol Geriatr[Internet]. 2012[cited 2016 Apr 20];54(2):370-3. Available from: http://www.pubfacts.com/fulltext/21570727/ Setting-the-criterion-for-fall-risk-screening-for-healthy-community-dwelling-elderly

6. Gomes EC, Marques AP, Leal MC, Barros BP. Fatores associados ao risco de quedas em idosos institucionalizados: uma revisão integrativa. Ciênc Saúde Colet[Internet]. 2014[cited 2016 Apr 20];19(8):3543-51. Available from: http://www.scielo.br/pdf/csc/v19n8/1413-8123csc-19-08-03543.pdf

7. Secretaria de Estado de São Paulo (SP). Relatório global da OMS sobre prevenção de quedas na velhice. São Paulo: Centro de Produção e Divulgação Científica; 2010.

8. Freitas MG, Bonolo FF, Moraes EM, Machado CJ. Idosos atendidos em serviços de urgência no Brasil: um estudo para vítimas de quedas e de acidentes de trânsito. Ciênc Saúde Colet[Internet]. 2015[cited 2016 May 15];20(3):701-12. Available from: http://www.scielo.br/pdf/ csc/v19n8/1413-8123-csc-19-08-03543.pdf

9. Cruz DT, Ribeiro LC, Vieira ML, Teixeira MTB, Bastos RR, Leite ICG. Prevalência de quedas e fatores associados em idosos. Rev Saúde Pública[Internet]. 2011[cited 2016 May 15];46(1):138-46. Available from: http://www.scielo.br/pdf/rsp/v46n1/3070.pdf

10. Bekibele CO, Gureje O. Fall incidence in a population of elderly persons in Nigeria. Gerontology [Internet]. 2010 [cited 2016 Apr 20];56(3):278-83. Available from: http://www.karger.com/Article/Abstract/236327/abstract

11. Fong KNK, Siu AMH, Yeung KA, Cheung SWS, Chan CCH. Falls among the community-living elderly people in Hong Kong: a retrospective study. HKJOT [Internet]. 2011[cited 2016 May 15];21(1):33-40. Available from: http://hdl.handle.net/10397/22160

12. Paula FL, Fonseca MJM, Oliveira RVC, Rozenfeld S. Perfil de idosos com internação por quedas nos hospitais públicos de Niterói (RJ). Rev Bras Epidemiol[Internet]. 2010[cited 2016 May 15];13(4):587-95. Available from: http://www.scielo.br/pdf/rbepid/ v13n4/04.pdf

13. Tarazona-Santabalbina FJ, Belenguer-Varea A, Rovira-Daudi E, Salcedo-Mahiques E, Cuesta-Peredó D, Doménech-Pascual JD, et al. Early interdisciplinary hospital intervention for elderly patients with hip fractures: functional outcome and mortality. Clinics[Internet]. 2012[cited 2016 May 15];67(6):547-55. Available from: http://www.ncbi.nlm.nih.gov/pmc/articles/PMC3370304

14. Arliani GG, Astur DC, Linhares GK, Balbachevsky D, Fernandes HJA, Reis FB. Correlação entre o tempo cirúrgico e mortalidade em pacientes idosos com fratura de extremidade proximal do fêmur. Rev Bras Ortop[Internet]. 2011[cited 2016 Apr 20];46(2):18994. Available from: http://www.scielo.br/pdf/rbort/v46n2/a13v46n2.pdf

15. Caberlon; IC, Bós AJG. Diferenças sazonais de quedas e fraturas em idosos gaúchos. Ciênc Saúde Colet[Internet]. 2015 [cited 2016 Apr 20];20(12):3743-52. Available from: http://www.scielo.br/pdf/csc/v20n12/1413-8123-csc-20-12-3743.pdf

16. Cruz DT, Ribeiro LC, Vieira MT, Teixeira MTB, Bastos RR, Leite ICB. Prevalência de quedas e fatores associados em idosos. Rev Saude Pública[Internet]. 2012[cited 2016 May 15];46(1):138-46. Available from: http://www.scielo.br/pdf/rsp/v46n1/3070.pdf

17. Gasparoto PR, Falsarella GR, Coimbra AMV. As quedas no cenário da velhice: conceitos básicos e atualidades da pesquisa em saúde. Rev Bras Geriatr Gerontol[Internet]. 2014[cited 2016 May 15];17(1):201-9. Available from: http://www.scielo.br/pdf/rbgg/v17n1/18099823-rbgg-17-01-00201.pdf

18. Strauss A, Corbin J. Basics of qualitative research: techniques and procedures for developing grounded theory. 3rd ed. Thousand Oaks: Sage; 2008.

19. Charon JM. Symbolic interactionism: an introduction, an interpretation, an integration. Englewood Cliffs (NJ): Prentice Hall; 1989.

20. Loganathan A, Ng CJ, Low WY. Views and experiences of Malaysian older persons about falls and their prevention: a qualitative study. BMC Geriatr[Internet]. 2016[cited 2016 Sep 12];16(97). Available from: http://www.ncbi.nlm.nih.gov/pmc/articles/PMC4858905/.

21. Weston JM, Norris EV, Clark EM. The invisible disease: making sense of an osteoporosis diagnosis in older age. Qual Health Res[Internet]. 2011[cited Sep 12];21(12):1692-704. Available From: http://www.ncbi.nlm.nih.gov/pubmed/21810994

22. Alami S, Hervout L, Poiraudeau S, Briot k, Roux C. Barriers to effective postmenopausal osteoporosis treatment: a qualitative study of patients' and practitioners' vews. PLoS One[Internet]. 2016[cited Sep 12];11(6). Available from: http://www.ncbi.nlm.nih.gov/ pubmed/27355576

23. Chen S-F, Huang S-F, Lu L-T, Wang M-C, Liao J-Y, Guo J-L. Patterns of perspectives on fall-prevention beliefs by community-dwelling older adults: a Q method investigation. BMC Geriatr[Internet]. 2016[cited Sep 12];16(132). Available from: http://www.ncbi.nlm.nih.gov/pmc/ articles/PMC4936088

24. Fhon JRS, Fabricio-Wehb SCCF, Vendrusculo TRP, Stackfleth R, Marques S, Rodrigues RAP. [Accidental falls in the elderly and their relation with functional capacity]. Rev Latino-Am Enfermagem[Internet]. 2012[cited 2016 Apr 20];20(5):[8 pages]. Available from: http://www.scielo.br/pdf/rlae/v20n5/pt_15.pdf Portuguese.

25. Brito TA, Fernandes MH, Coqueiro RS, Jesus CS. Quedas e capacidades funcional em idosos longevos residentes em comunidade. Texto Contexto Enferm[Internet]. 2013[cited 2016 May 15];22(1):43-51. Available from: http://www.scielo.br/pdf/tce/v22n1/pt_06.pdf 
26. Carvalho CMR, Garcês JR, Menezes RL, Silva, ECF. O olhar e o sentir do idoso no pós-queda. Rev Bras Geront[Internet]. 2010 [cited 2016 Apr 20];13(1):7-16. Available from: http://www.scielo.br/pdf/rbgg/v13n1/a02v13n1.pdf

27. Lopes RA, Dias RC. O impacto das quedas na qualidade de vida dos idosos. Rev ConScientiae Saúde[Internet]. 2010 [cited 2016 May 15];9(3):504-9. Available from: http://www.redalyc.org/pdf/929/92915180022.pdf

28. Yardley L, Bishop FL, Beyer N, Hauer K, Kempen Gl, Piot-Ziegler C, et al. Older people's views of falls-prevention interventions in six European countries. Gerontologist[Internet]. 2006[cited 2016 Apr 20];46(5):650-60. Available from: http://www.ncbi.nlm.nih.gov/ pubmed/17050756/abstract

29. Agmon M, Armon G. A cross-sectional study of the association between mobility test performance and personality among older adults. BMC Geriat[Internet]. 2016[cited 2016 Jun 17]16(1). Available from: https://bmcgeriatr.biomedcentral.com/ articles/10.1186/s12877-016-0272-8

30. Laing SS, Silver IF, York S, Phelan EA. Fall prevention knowledge, attitude, and practices of community stakeholders and older adults. J Aging Res[Internet]. 2011[cited 2016 May 20]:2011[9 pages]. Available from: http://www.hindawi.com/journals/jar/2011/395357/. 